\title{
Fruit Traits at Harvest and After Storage Related to the Incidence of Postharvest Physiological Disorders in 'Keitt' Mangoes
}

\section{Matheus Elysio Ayres de Andrade ${ }^{1}$, Bárbara Orrana Sobreira da Silva ${ }^{2}$, Tiffany da Silva Ribeiro ${ }^{2}$, Luana Ferreira dos Santos ${ }^{3}$, Augusto Miguel Nascimento Lima ${ }^{1}$, Fábio Freire de Oliveira ${ }^{4}$ and Sergio Tonetto de Freitas $^{3 *}$}

${ }^{1}$ Federal University of São Francisco Valley, Agronomy Graduate Program, Petrolina,

PE, Brazil.

${ }^{2}$ Pernambuco University, Biology Department, Petrolina, PE, Brazil

${ }^{3}$ Brazilian Agricultural Research Corporation, Embrapa, Petrolina, PE, Brazil

${ }^{4}$ Federal Institute of Education, Agronomy Department, Petrolina, PE, Brazil

*Corresponding Author: Sergio Tonetto de Freitas, Brazilian Agricultural Research

Corporation, Embrapa, Petrolina, PE, Brazil.
Received: October 30, 2021

Published: December 16, 2021

(C) All rights are reserved by Sergio Tonetto

de Freitas., et al.

\begin{abstract}
Physiological disorders are among the most important causes of mango postharvest loss. Therefore, the objectives of this study were to identify at harvest and after storage fruit physical and chemical traits related to the incidence of internal physiological disorders in 'Keitt' mangoes. A total of 200 'Keitt' mangoes were harvested at the commercial maturity. After the harvest, one half of each fruit without the seed was cut longitudinally and evaluated, while the other half containing the seed was treated with sodium hypochlorite at $1000 \mu \mathrm{L} \mathrm{L}^{-1}$, covered with a polyvinyl chloride (PVC) film and stored at $10^{\circ} \mathrm{C}$ until the flesh firmness reached $<15 \mathrm{~N}$, which was considered ready-to-eat maturity. According to the results, the physiological disorders incidence after storage reached $9 \%$ for jelly seed, $9 \%$ for black flesh and $11 \%$ for spongy tissue. There were no differences between fruit with and without disorders for AA, SS, TA, and DM analyzed at harvest and after storage. Mangos that developed spongy tissue had at harvest higher skin hue angle, lower levels of calcium (Ca), magnesium (Mg), zinc ( $\mathrm{Zn})$, copper (Cu), iron (Fe) and $\mathrm{Ca} / \mathrm{B}$ ratio, as well as higher levels of manganese (Mn) and N/Ca, K/Mg, K/Ca ratios, compared to sound fruit. Mangoes that developed jelly seed symptoms had at harvest lower levels of total extractable polyphenols (TEP), total antioxidant capacity (TAC), Ca, Mg, Zn, as well as higher Mn levels and N/Ca, Ca/Mg, K/ $\mathrm{Mg}, \mathrm{K} / \mathrm{Ca}$ ratios, compared to sound fruit. Flesh nutrient concentrations remained the same in each fruit from harvest to the end of storage. After storage, mangos with jelly seed symptoms showed higher skin hue angle and TEP levels, as well as lower TAC, compared to healthy fruit. Mangos that developed black flesh symptoms had higher levels of N, Mn and N/Ca, K/Mg, K/Ca ratios, as well as lower $\mathrm{Ca}, \mathrm{Mg}, \mathrm{Zn}, \mathrm{Cu}, \mathrm{Fe}$ and $\mathrm{Ca} / \mathrm{B}$ ratios at harvest, compared to sound mangoes. After storage, mangoes with black flesh symptoms had darker skin (lower L) and lower skin C and b values, as well as higher TEP levels, compared to sound fruit. In conclusion, the skin hue angle and TEP levels in flesh tissue have the potential to predict at harvest and determined after storage the incidence of spongy tissue and jelly seed in 'Keitt' mangoes, respectively. Skin L, C and b values have the potential to non-destructively determine the presence of black flesh in ready-to-eat 'Keitt' mangoes. Mangoes that developed black flesh, jelly seed and spongy tissue during storage had at harvest low levels of $\mathrm{Ca}, \mathrm{Mg}$, and $\mathrm{Zn}$, as well as high Mn levels, compared to healthy fruit. More studies are required to determine the level of each physicochemical and nutritional trait that can be used as an index to predict at harvest or identify readyto-eat fruit with physiological disorders.
\end{abstract}

Keywords: Black Flesh; Jelly Seed; Spongy Tissue; Internal Physiological Disorders 


\section{Introduction}

In Brazil, the São Francisco Valley is the most important mango growing region, which is responsible for about $77 \%$ of the total production and $90 \%$ of mango export [1]. Despite its economic importance, mango production has important limitations that need to be overcome to ensure higher consumption, production and development of the growing regions. Among the limitations is the high incidence of physiological disorders that can result in great financial losses throughout the mango industry, reaching up to $30 \%$ of losses at the final market $[2,3]$.

Physiological disorders are the result of abnormal changes in cell metabolism that lead to tissue damage and death, resulting in undesirable symptoms that make fruit consumption unfeasible $[4,5]$. In mangoes, these disorders result in significant fruit and economical losses [2]. Although several strategies have been adopted to minimize postharvest losses due to physiological disorders, the success of these strategies is not always effective because of lack of knowledge about the mechanisms triggering these disorders in mangoes [6,7]. Among the most important internal physiological disorders are the jelly seed, black flesh, and spongy tissue $[5,8]$.

The jelly seed is characterized by the watery and jelly appearance of the flesh close to the seed [5]. Studies have suggested that one of the possible causes of this disorder is the premature seed germination in the fruit, which is possibly triggered by a hormonal imbalance related to increasing gibberellin synthesis and drop in abscisic acid concentrations [2,9]. Other studies have shown that jelly seed is initially characterized by a more intense yellow color of the flesh tissue close to the seed, compared to the rest of the flesh, which becomes even more intense with ripening, culminating with a jelly and watery texture at final stages of development [10]. In addition, it has also been observed a reduction in the levels of total sugars, greater activity of the enzymes alpha-amylase, polyphenol oxidase, pectin-methylesterase and cellulase, as well as a higher respiration rate in the flesh of mangoes with jelly seed symptoms [9]. Other studies have also reported a reduction in the concentration of free fatty acids in the seed of jelly seed fruit, which has been suggested to be related to the increasing synthesis of cytokinins that could have triggered seed germination events [8].

The black flesh is a disorder reported in mangoes produced in the Americas, mainly in Brazil, Peru and Mexico. The symptoms of this disorder are characterized by dark-brown and dry inner flesh tissues in the fruit [11]. This disorder has also been observed in
'Haden' mangoes stored at $13^{\circ} \mathrm{C}$, which was the first study describing the incidence of the disorder [12]. Later, black flesh was also reported in other mango cultivars such as Tommy Atkins, Keitt, Kent and Ataulfo [5]. Although studies have suggested fruit susceptibility to black flesh could be affected by pre-harvest and postharvest conditions, there are no conclusive information about the main factors regulating black flesh incidence in mangoes [5].

The spongy tissue is characterized by the presence of brownwhitish and dry cavities with a spongy aspect in the inner flesh of the fruit [13]. It has been state that the origin of the spongy tissue in 'Alphonso' mango is very similar to the origin of the jelly seed in 'Amrapali' mango, in which the seed has a reduction in the long and short chains of fatty acids, leading to an increase in synthesis cytokinins and germination [8]. According to this study, at the beginning of germination, water moves from the flesh to the seed, and there is an increase in the activity of the enzymes pectin methylesterase, polygalacturonase and pectate lyase in the flesh that leads to a rapid degradation of pectins and the spongy tissue symptoms.

Although studies have reported possible factors regulating internal disorders in mangoes, several other factors may be involved, which can be identified and used as indicators of fruit susceptibility to these disorders. Such factors can be used at harvest to predict the incidence of the disorders in the fruit during ripening, as well as non-destructive factors can be used to sort sound and disordered fruit in the final market, ensuring the quality of the fruit to consumers. In addition, there is limited information about the most important factors regulating physiological disorders in mangoes and new studies will help developing more efficient control approaches, improving fruit production efficiency by reducing losses.

The objectives of this study were to identify at harvest and after storage fruit physical and chemical traits related to the incidence of internal physiological disorders in 'Keitt' mangoes.

\section{Material and Methods}

A total of 200 'Keitt' mangoes were harvested at the commercial maturity in an orchard located in Belém do São Francisco, PE, Brazil ( $\left.08^{\circ} 45^{\prime} 14^{\prime \prime} \mathrm{S}, 38^{\circ} 57^{\prime} 57^{\prime \prime} \mathrm{W}\right)$. The region's climate is classified as BSh, according to the Köppen classification. After harvest, the fruit were transported to the Postharvest laboratory at the Tropical Semi-arid Embrapa, Petrolina, PE, Brazil.

At harvest, each fruit was cut longitudinally in half, resulting in one side with and other without the seed. The fruit side without 
the seed was considered an individual sample and was subjected to physical and chemical analyzes at harvest. The side containing the seed was quickly immersed in a solution of sodium hypochlorite at $1000 \mu \mathrm{L} \mathrm{L}^{-1}$ for one minute, and then the cut surface was wrapped with a polyvinyl chloride (PVC) film, and the fruit half was stored at $10^{\circ} \mathrm{C}$ until the flesh reached firmness equal or lower than $15 \mathrm{~N}$, which was considered the ready-to-eat maturity.

At harvest, the fruit half was peeled and cut in half in the equatorial region. The peduncle half was discarded, and the distal half was then divided into three longitudinally equal samples that were used for physical and chemical analyzes. One sample was dried in a drying oven at $60^{\circ} \mathrm{C}$ and used for macro and micronutrient analysis, while another sample was frozen for the analysis of ascorbic acid (AA), total extractable polyphenols (TEP) and total antioxidant capacity (TAC). The third sample was used for the analysis of titratable acidity (TA) and soluble solids (SS).

After reaching $15 \mathrm{~N}$ of flesh firmness, the stored fruit half was then cut from the seed and the flesh tissue was sampled in the same way as the fruit half analyzed at harvest. In this fruit half, the absence of internal physiological disorders (healthy fruit), as well as the incidence of jelly seed, black flesh and spongy tissue were evaluated based on the visual appearance presented in figure 1. Fruit with decay symptoms were discarded. The treatments were composed by fruit that had no incidence of disorders (healthy), fruit that developed jelly seed, black flesh, or spongy tissue during storage. Each treatment was composed by five replications and each replication by 3 fruit. After storage, fruit were evaluated as described at harvest.

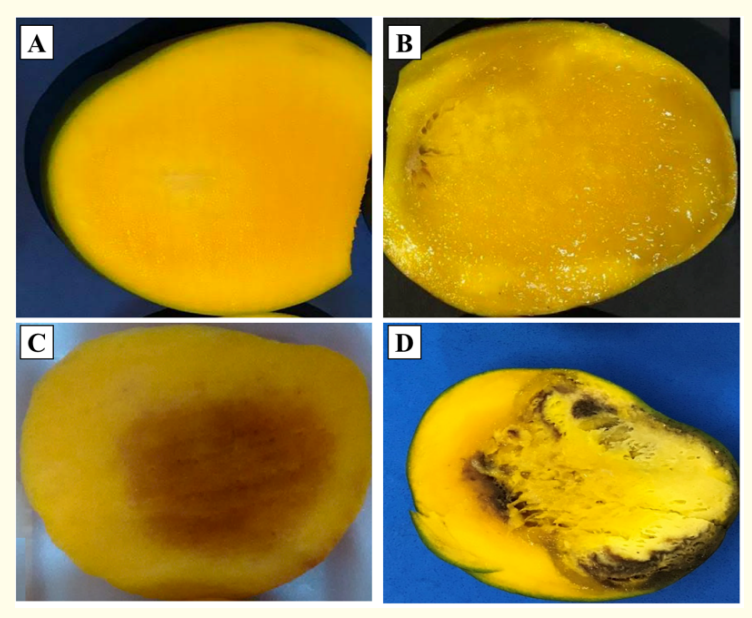

Figure 1: 'Keitt' mangoes without physiological disorders (A) or showing visual symptoms of jelly seed (B), black flesh (C) and spongy tissue (D).
Skin color was determined with a digital colorimeter model CR400 (Minolta, Tokyo, Japan). The results were expressed as lightness $\left(L^{*}\right)$ that corresponds to the variation from black $(0)$ to white (100), chroma $\left(\mathrm{C}^{*}\right)$ that represents the color intensity from $0=$ impure color to $60=$ pure color, Hue angle $(\stackrel{\circ}{\circ})$ that is represented as $0^{\circ}=$ red, $90^{\circ}=$ yellow, $180^{\circ}=$ green, and $270^{\circ}=$ blue, a $*$ that ranges from green (-) to red $(+)$, and $b^{*}$ that ranges from blue $(-)$ to yellow $(+)$, as the sum between $a+b$.

Ascorbic acid (AA) was determined based on the Tillman method [14]. Briefly, the Tillman solution was prepared at $0.02 \%$ (DFI - 2,6 dichloro-phenol indophenol). Sample extracts were obtained by adding $5 \mathrm{~g}$ of flesh juice in $100 \mathrm{~mL}$ of $0.5 \%$ oxalic acid. Later, 4 $\mathrm{mL}$ of the extract was added in $50 \mathrm{~mL}$ of cold distilled water, which was then titrated with Tillman's solution until pink color development. Two replicates were used for each sample.

Soluble solids (SS) were determined by adding two drops of fruit juice in a digital refractometer model $\mathrm{PAL}^{-1}$ (Atago, São Paulo, Brazil). Titratable acidity (TA) was determined in $1 \mathrm{~g}$ of fruit juice, which was diluted in $50 \mathrm{~mL}$ of distilled water and titrated with sodium hydroxide $0.1 \mathrm{~N}$ until $\mathrm{pH}$ 8.1. Titration was accomplished with an automatic titrator model Titrino Plus 848 (Metrohm, São Paulo, Brazil). The results were expressed as a percentage of citric acid.

Dry matter (DM) content was determined by weighting fresh samples, which were dried at $65^{\circ} \mathrm{C}$ until constant weight to determine the dry weight. The DM was calculated by multiplying the dry weight by 100 , which was then divided by the initial fresh weight of each sample, with the results expressed as a percentage.

Total antioxidant capacity (TAC): Initially, an extract was obtained for each sample by dissolving $8 \mathrm{~g}$ of flesh in $20 \mathrm{~mL}$ of $50 \%$ methanol, which was maintained at $25^{\circ} \mathrm{C}$ for $1 \mathrm{~h}$. The sample was then centrifugated at 50,000g for $15 \mathrm{~min}$ and the supernatant was filtered and transferred to a $50 \mathrm{~mL}$ flask. The residue was transferred to another flask with $20 \mathrm{~mL}$ of $70 \%$ acetone, which was extracted at $25^{\circ} \mathrm{C}$ for $1 \mathrm{~h}$. The centrifugation was repeated, and the supernatant was filtered and added to the flask that already contained the supernatant from the first extraction, and the total volume was then completed with distilled water up to $50 \mathrm{~mL}$. The antioxidant activity was determined by the capture of DPPH (1,1-diphenyl-2-picryl-hydrazil) free radicals. The standard curve was stablished by different concentrations of gallic acid $(0,200$, $400,600 \mathrm{~mL} \mathrm{~L}^{-1}$ ). A total of $100 \mu \mathrm{L}$ of each sample was added to 3.9 $\mathrm{mL}$ of DPPH $(0,06 \mathrm{mM})$, which was incubated in the dark at $25{ }^{\circ} \mathrm{C}$ for $30 \mathrm{~min}$. All samples were analyzed at $515 \mathrm{~nm}[15,16]$. 
Total extractable polyphenols (TEP) were determined by the Folin-Ciocalteu method, using the sample supernatant obtained in the TAC analysis. In test tubes, $0.1 \mathrm{~mL}$ of each sample supernatant was added to $0.9 \mathrm{~mL}$ of distilled water. The extract was mixed with $1 \mathrm{~mL}$ of Folin-Ciocalteu reagent, $2 \mathrm{~mL}$ of $20 \%$ sodium carbonate solution and $2 \mathrm{~mL}$ distilled water. The tubes were shaken and after $30 \mathrm{~min}$ the absorbance was measured at $700 \mathrm{~nm}$ [17].

Macro and micronutrients were analyzed in flesh samples that were dried at $65^{\circ} \mathrm{C}$ until constant weight. Dried samples were ground to a fine powder and subjected to the analyses of $\mathrm{N}, \mathrm{K}, \mathrm{P}$, $\mathrm{Ca}, \mathrm{Mg}, \mathrm{B}, \mathrm{Zn}, \mathrm{Fe}, \mathrm{Cu}$, and $\mathrm{Mn}$ concentrations, as well as N/B, N/Ca, $\mathrm{N} / \mathrm{Mg}, \mathrm{K} / \mathrm{Ca}, \mathrm{K} / \mathrm{Mg}$ and $\mathrm{Ca} / \mathrm{Mg}$ ratios. Briefly, $500 \mathrm{mg}$ of dry sample was added to $5 \mathrm{~mL}$ of concentrated sulfuric acid and placed in the digest block at $350^{\circ} \mathrm{C}$ for $30 \mathrm{~min}$. After cooling at room temperature for five minutes, $0.5 \mathrm{~mL}$ of hydrogen peroxide was added to each sample. Then, the sample returned to the digest block at 350 ${ }^{\circ} \mathrm{C}$ for eight minutes, repeating this procedure until the liquid had a light color. After reaching the light color, the sample was kept in the digest block at $350^{\circ} \mathrm{C}$ for 30 min to remove hydrogen peroxide from the solution. After cooling, the samples were diluted to $25 \mathrm{~mL}$ and subjected to nutrient analyzes as described in previous studies $[18,19]$. Nitrogen was determined by the Kjeldahl method, P by spectrometry with yellow vanadate, $\mathrm{K}$ and Na by flame-photometry, Mg, Ca, Fe, Zn and Mn by atomic absorption spectrophotometry, and $\mathrm{B}$ by spectrophotometry with azomethine-H.

The study followed a completely randomized design, as a factorial $4 \times 2$ (physiological disorder $\mathrm{x}$ evaluation date). The data obtained were subjected to the analysis of variance and mean values were compared by the Tukey test $(\mathrm{p} \leq 0.05)$. The statistical analysis was performed with the Sisvar version 5.1 software. The data were also subjected to the principal component analysis (PCA), using the Statistica Software 10.

\section{Results}

According to the results, a total of $29 \%$ of mangoes had some type of physiological disorder at the end of storage at $10^{\circ} \mathrm{C}$, when the fruit reached flesh firmness equal to or lower than $15 \mathrm{~N}$, with $11 \%$ showing spongy tissue, 9\% black flesh, and 9\% jelly seed symptoms (Figure 2).

The interaction between physiological disorder and evaluation date had a significant effect on skin L value. At harvest, skin L was equal in all treatments (Figure 3A). After storage, fruit with black flash symptoms had darker skin than healthy fruit (Figure 3A). Mangoes that developed black flesh symptoms showed skin darkening during ripening, which was not observed in healthy mangoes after storage (Figure 3A).

The skin $C$ value was affected by the interaction between physiological disorder and evaluation date. At harvest, the $C$ value was equal in healthy and all disordered fruit (Figure 3B). After storage, fruit with black flesh had lower skin $C$ value than healthy fruit (Figure 3B). Healthy, jelly seed, and spongy tissue fruit showed an increase in skin $\mathrm{C}$ values during storage (Figure $3 \mathrm{~B}$ ).

The skin $\mathrm{h}^{\circ}$ was affected by the interaction between physiological disorder and evaluation date. At harvest or after storage, fruit that developed spongy tissue or jelly seed symptoms had higher $\mathrm{H}^{\circ}$ values, compared to healthy fruit, respectively (Figure $3 \mathrm{C}$ ). The skin $\mathrm{h}^{\circ}$ value decrease or increased during storage in fruit that developed spongy tissue or jelly seed, respectively (Figure 3C).

The skin a value was not affected by neither the interaction or each individual factor, physiological disorder and evaluation date. The skin $b$ and $a+b$ values were affected by the interaction between physiological disorder and evaluation date. At harvest, the $b$ and $a+b$ values were similar among healthy and disordered fruit (Figure 3D, 3E). After storage, fruit with black flesh had lower $b$ and $a+b$ values, compared to all other fruit (Figures 3E, 3F). Healthy fruit, as well as jelly seed and spongy tissue fruit showed an increase in $b$ and $a+b$ values during storage, which was not observed in black flesh fruit (Figures 3E, 3F).

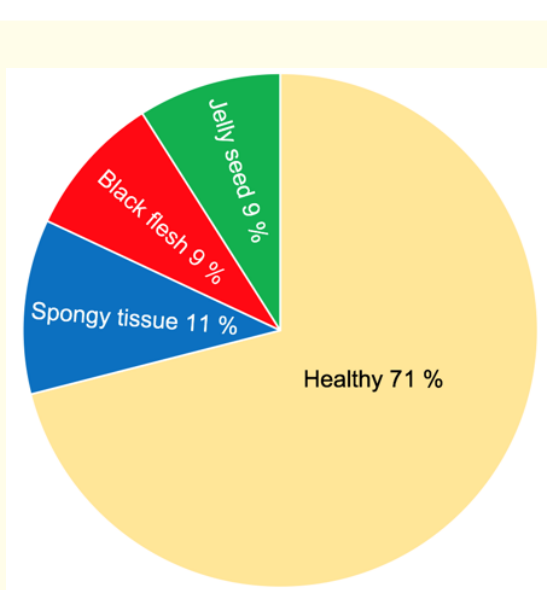

Figure 2: Incidence of black flesh, jelly seed and spongy tissue physiological disorders in 'Keitt' mangoes stored at $10^{\circ} \mathrm{C}$ until the fruit reached flesh firmness equal to or lower than $15 \mathrm{~N}$. 

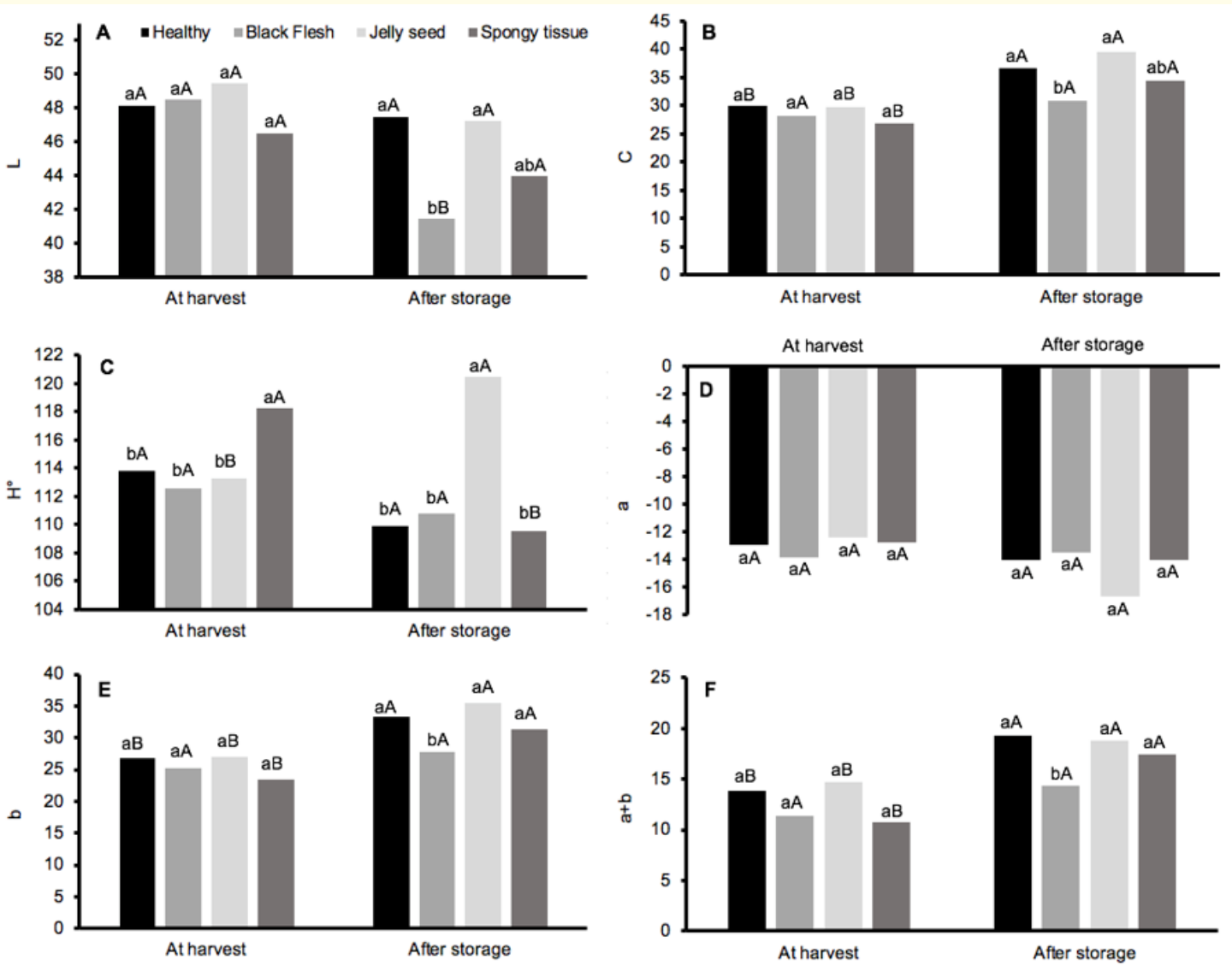

Figure 3: Lightness (A), chromaticity (B), hue angle (C), a (D), b (E) and a+b (F) skin color values of 'Keitt' mangoes at harvest and after storage at $10{ }^{\circ} \mathrm{C}$. Lowercase letters compare physiological disorders at harvest or after storage. Capital letters compare the same fruit at harvest and after storage. Mean values followed by the same letter are statistically equal according to the Tukey test $(\mathrm{p} \leq 0.05)$.

The AA, SS, TA and DM contents were not affected by physiological disorders, both at harvest and after storage (Figures 4A, 4B, 4C and $4 \mathrm{D})$. The SS content increased during storage, whereas AA, TA and DM contents decreased during the storage (Figures 4A, 4B, 4C and 4D).

The TEP content in the fruit was affected by the interaction between physiological disorder and evaluation date. At harvest, fruit that developed jelly seed during storage had the lowest TEP levels, compared to all other fruit (Figure 4E). After storage, the lowest TEP levels were observed in healthy and spongy tissue fruit, whereas the highest TEP levels were observed in black flesh fruit (Figure 4E). During storage, the TEP levels decreased in healthy and spongy tissue fruit, increased in jelly seed fruit, and remained the same black flesh fruit (Figure 4E).

The fruit TAC was affected by the interaction between physiological disorder and evaluation date. The DPPH method measures the scavenging potential of antioxidant extracts, based on its capacity as a hydrogen donor and electron transfer [20]. Therefore, lower values represent greater TAC. At harvest, the highest TAC was observed in healthy, black flesh and spongy tissue fruit, whereas the lowest TAC was observed in jelly seed fruit (Figure 4F). After the storage, the highest TAC was observed in healthy and spongy tissue fruit, whereas the lowest TAC was observed in jelly seed fruit (Figure 4F). During the storage, healthy, black flesh and jelly seed fruit showed a decrease in TAC, whereas spongy tissue fruit had no change in TAC (Figure 4F). 

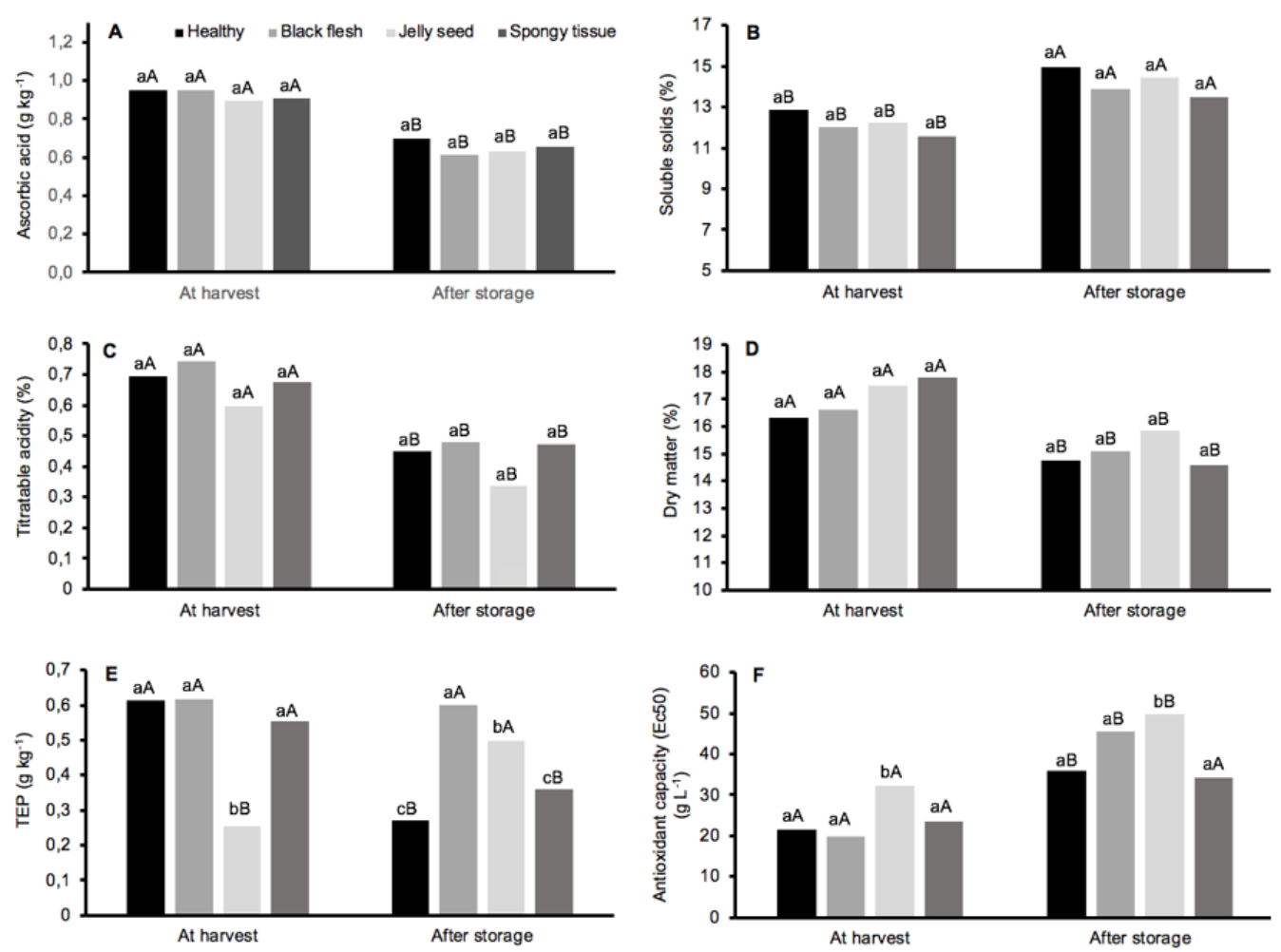

Figure 4: Ascorbic acid (A), soluble solids (B), titratable acidity (C), dry matter (D), total extractable polyphenols (E), and total antioxidant capacity (F) of 'Keitt' mangoes at harvest and after storage at $10^{\circ} \mathrm{C}$. Lowercase letters compare physiological disorders at harvest or after storage. Capital letters compare the same fruit at harvest and after storage. Mean values followed by the same letter are statistically equal according to the Tukey test $(\mathrm{p} \leq 0.05)$.

Although the nutrient analyzes were accomplished both at harvest and after storage, there were no statistical differences between nutrient concentrations in each fruit at harvest and after storage. Therefore, nutrient results were presented as the average concentration between the analyzes accomplished at harvest and after storage in each fruit (Figures 5, 6 and 7). According to the results, $\mathrm{N}$ concentration was higher in fruit that developed black flesh during storage, compared to healthy fruit (Figure 5A). Potassium concentration was similar among healthy and disordered fruit (Figure 5B). Calcium and magnesium concentrations were higher in healthy fruit and lower in black flesh, jelly seed and spongy tissue fruit (Figures 5C and 5D). Sodium, boron and phosphorus con- centrations showed no statistical difference between healthy and disordered fruit (Figures 5E, 5F and 5G).

The N/B ratio had no significant difference between healthy and disordered fruit (Figure 6A). The N/Ca was lower in healthy fruit, intermediate in jelly seed fruit, and higher in black flesh and spongy tissue fruit (Figure 6B). The highest $\mathrm{Ca} / \mathrm{B}$ ratios were observed in healthy and jelly seed fruit, whereas the lowest values were observed in black flesh and spongy tissue fruit (Figure 6C). The $\mathrm{Ca} / \mathrm{Mg}$ ratio was lower in healthy and spongy tissue fruit, and higher in jelly seed followed by black flesh fruit (Figure 6D). The lowest $\mathrm{K} / \mathrm{Mg}$ and $\mathrm{K} / \mathrm{Ca}$ ratios were observed in healthy fruit, compared to all disordered fruit (Figures 6E and 6F). 

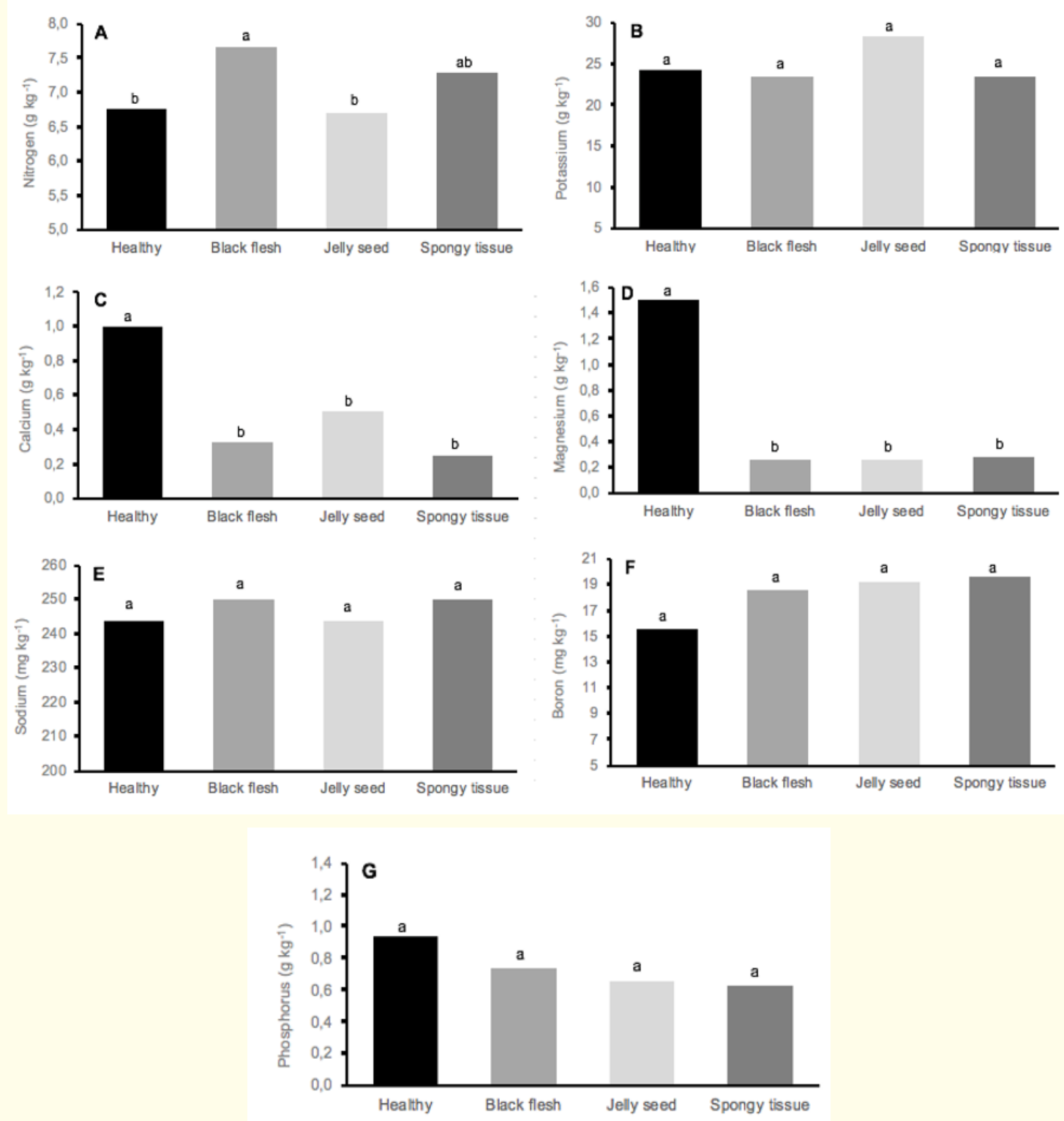

Figure 5: Concentrations of Nitrogen (A), Potassium (B), Calcium (C), Magnesium (D), Sodium (E), Boron (F) and Phosphorus (G) in 'Keitt' mangoes. No statistical difference was observed between nutrient concentrations in each fruit at harvest and after storage. Means were calculated with nutrient concentrations obtained at harvest and after storage in each fruit. Means followed by the same letter are statistically equal according to the Tukey test $(\mathrm{p} \leq 0.05)$. 

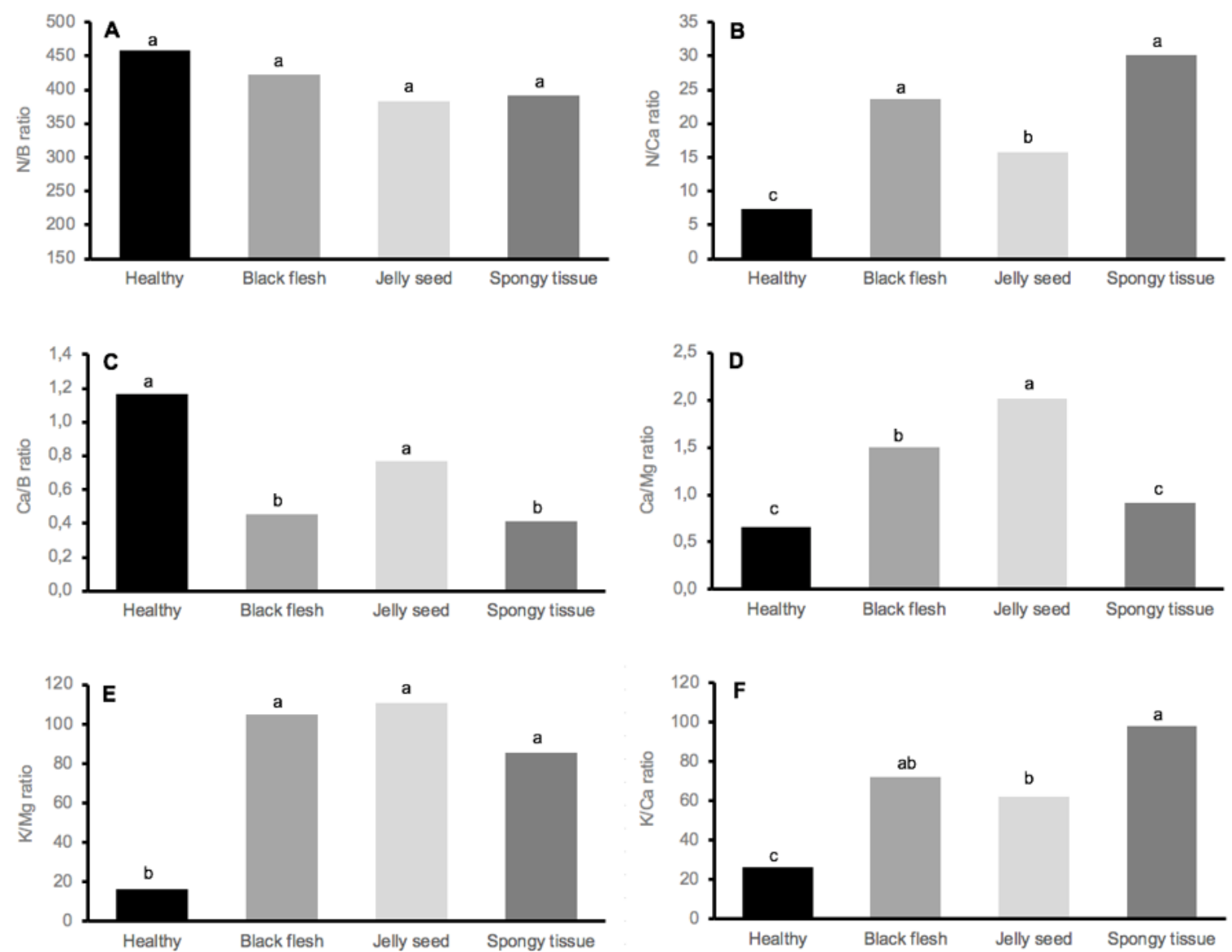

Figure 6: Ratios of N/B (A), N/Ca (B), Ca/B (C), Ca/Mg (D), K/Mg (E) and K/Ca (F) in 'Keitt' mangoes. No statistical difference was observed between nutrient concentrations in each fruit at harvest and after storage. Means were calculated with nutrient ratios obtained at harvest and after storage in each fruit. Means followed by the same letter are statistically equal according to the Tukey test ( $\mathrm{p} \leq 0.05$ ).

Zinc concentrations were higher in healthy fruit and lower in all disordered fruit (Figures 7A). Copper concentrations were higher in healthy fruit, intermediate in jelly seed fruit and lower in black flesh and spongy tissue fruit (Figure 7B). Iron concentration was higher in healthy and jelly seed fruit and lower in black flesh and spongy tissue fruit (Figure 7C). Manganese concentration was lower in healthy fruit and higher in all disordered fruit (Figure 7D).

The principal component analysis showed that healthy, black flesh, jelly seed, and spongy tissue fruit have different profiles for the variables analyzed (Figures 8 and 9). At harvest, it was verified that components I and II explained the variability of the experimental samples at $50.47 \%$ and $33.61 \%$, respectively (Figures $8 \mathrm{~A}$ and $8 \mathrm{~B}$ ). Healthy fruit were characterized by the AA, SS, $\mathrm{Mg}, \mathrm{P}, \mathrm{Cu}$, and Fe levels, as well as by the N/B ratio (Figures $8 \mathrm{~A}$ and $8 \mathrm{~B}$ ). Fruit that developed jelly seed were characterized by the $\mathrm{Ca}, \mathrm{Zn}$, and $\mathrm{K}$ levels, antioxidant activity, $\mathrm{Ca} / \mathrm{Mg}$ and $\mathrm{Ca} / \mathrm{B}$ ratios, and skin $\mathrm{L}, \mathrm{a}, \mathrm{b}$, $\mathrm{C}$, and $\mathrm{a}+\mathrm{b}$ values (Figures $8 \mathrm{~A}$ and $8 \mathrm{~B}$ ). Fruit that developed black flesh and spongy tissue, arranged in the same quadrant, were characterized by the $\mathrm{N}$ levels, $\mathrm{K} / \mathrm{Ca}$ and $\mathrm{N} / \mathrm{Ca}$ ratios, and skin $\mathrm{H}^{\circ}$ values (Figures 8A and 8B). 

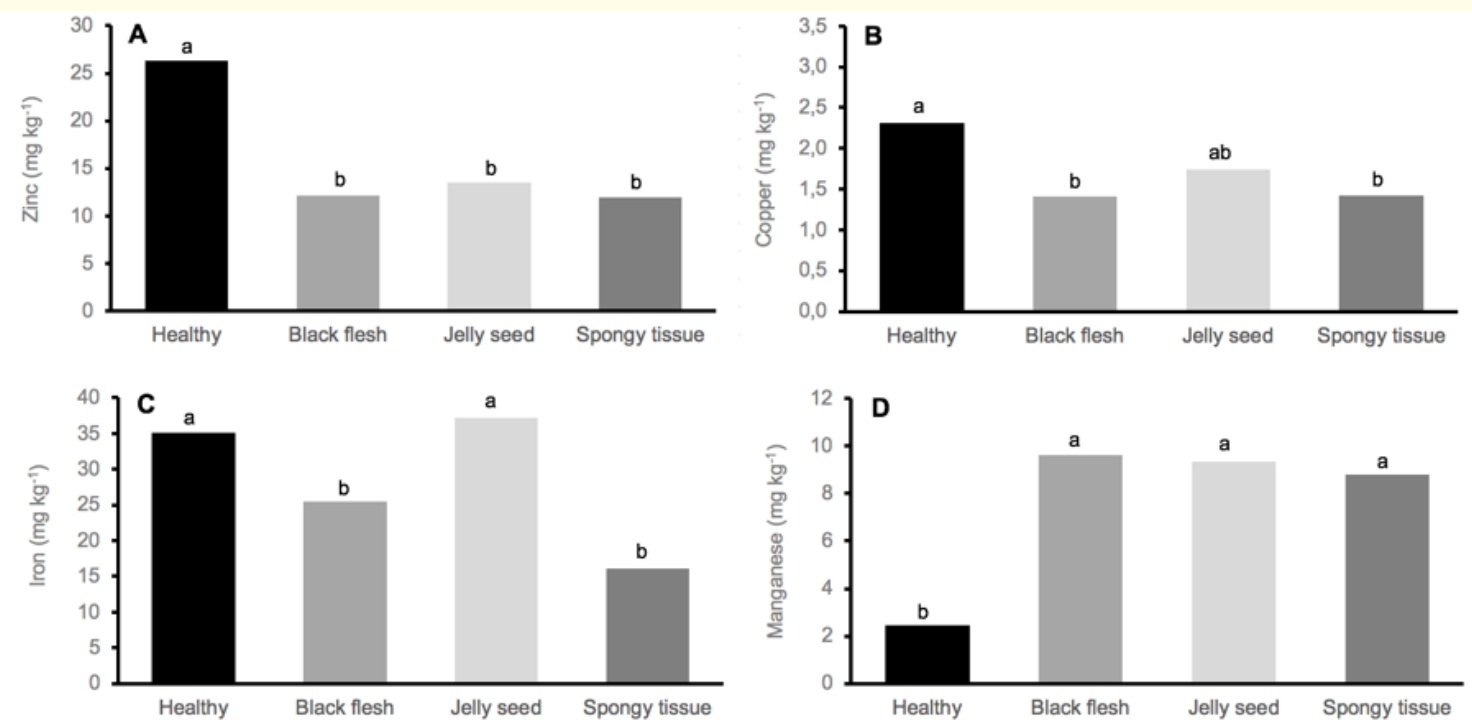

Figure 7: Concentrations of Zinc (A), Copper (B), Iron (C) and Manganese (D) in 'Keitt' mangoes. No statistical difference was observed between nutrient concentrations in each fruit at harvest and after storage. Means were calculated with nutrient concentrations obtained at harvest and after storage in each fruit. Means followed by the same letter are statistically equal according to the Tukey test ( $p \leq 0.05$ ).
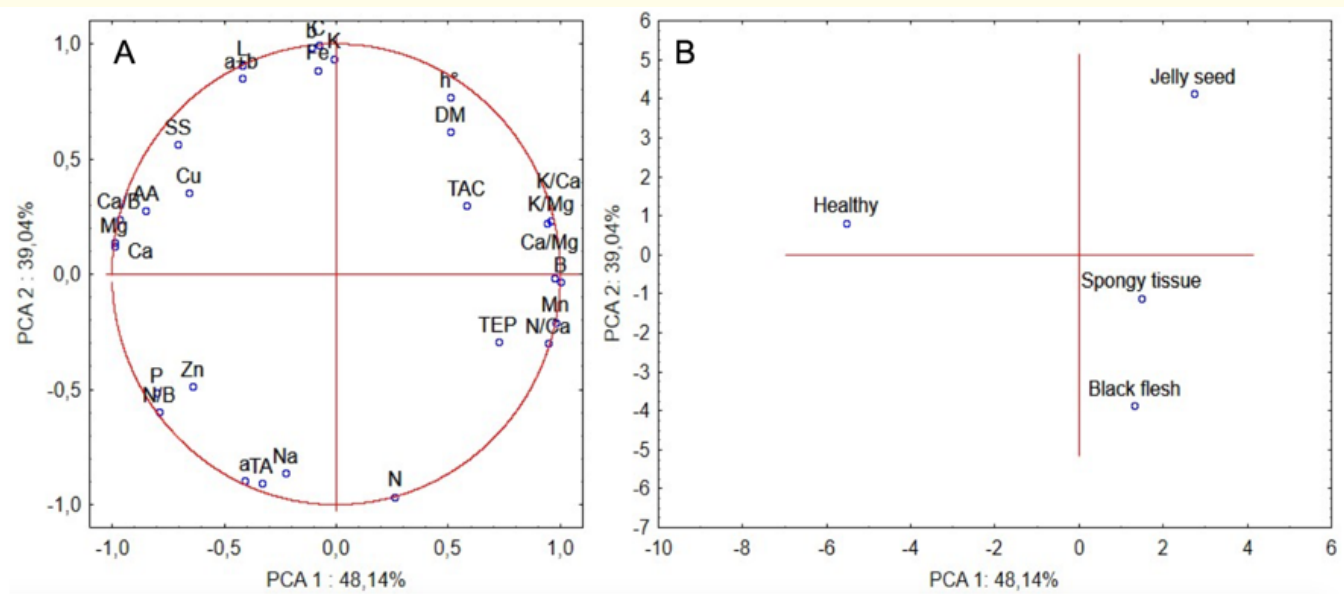

Figure 8: Two-dimensional projection of the data obtained after storage on the principal components I and II for the variables ascorbic acid (AA), soluble solids (SS), titratable acidity (TA), dry matter (DM), total extractable polyphenols (TEP), total antioxidant capacity (TAC), skin lightness $(\mathrm{L})$, skin chromaticity $(\mathrm{C})$, skin hue angle $\left(\mathrm{h}^{\circ}\right)$, skin color parameters $a, b, a+b$, nitrogen $(\mathrm{N})$, potassium $(\mathrm{K})$, calcium (Ca), magnesium (Mg), sodium $(\mathrm{Na})$, boron 
After storage, it was verified that components I and II explained the variability of the experimental samples at $48.14 \%$ and $39.04 \%$, respectively (Figures $9 \mathrm{~A}$ and $9 \mathrm{~B}$ ). Healthy fruit were characterized by $\mathrm{Ca}, \mathrm{Mg}$, and $\mathrm{Cu}$ levels, $\mathrm{Ca} / \mathrm{B}$ ratio, as well as by SS and AA levels (Figures 9A and 9B). Fruit that developed jelly seed were charac- terized by the skin $\mathrm{H}^{\circ}$ values, DM content, as well as by the TAC determined with the DPPH method (Figures 9A and 9B). Fruit that developed spongy tissue and black flesh were characterized by $\mathrm{N}$, $\mathrm{Mn}, \mathrm{B}$ and TEP levels, as well as by N/Ca and $\mathrm{Ca} / \mathrm{Mg}$ ratios (Figures 9A and 9B).
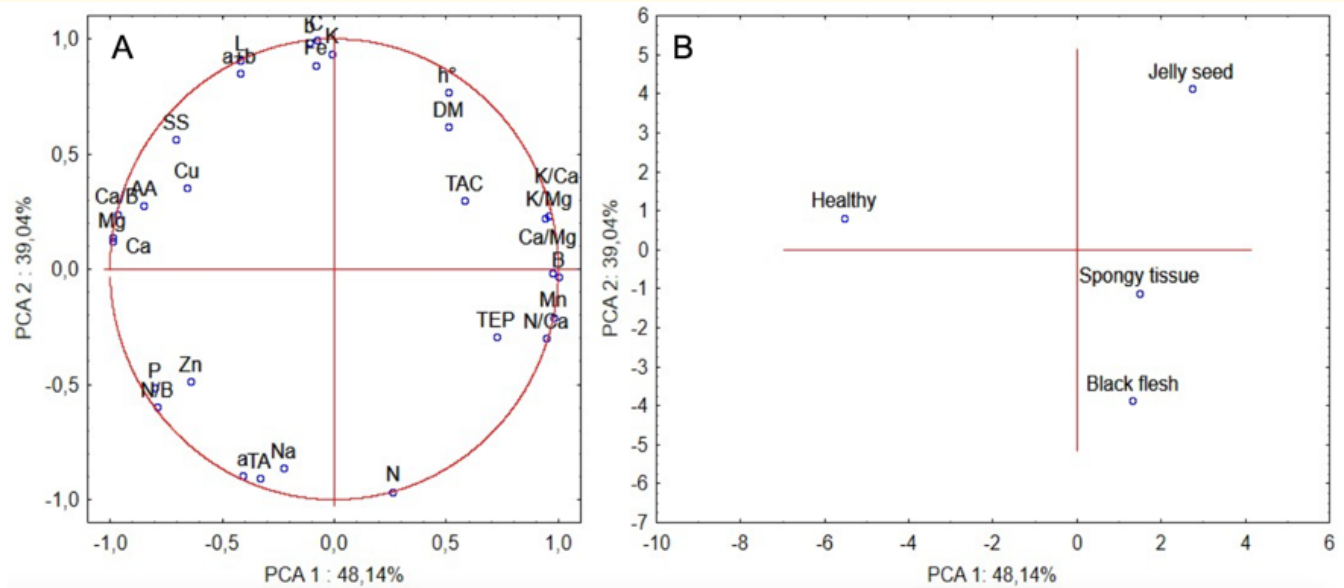

Figure 9: Two-dimensional projection of the data obtained after storage on the principal components I and II for the variables ascorbic acid (AA), soluble solids (SS), titratable acidity (TA), dry matter (DM), total extractable polyphenols (TEP), total antioxidant capacity $(\mathrm{TAC})$, skin lightness $(\mathrm{L})$, skin chromaticity $(\mathrm{C})$, skin hue angle $\left(\mathrm{h}^{\circ}\right)$, skin color parameters $\mathrm{a}, \mathrm{b}, \mathrm{a}+\mathrm{b}$, nitrogen $(\mathrm{N})$, potassium $(\mathrm{K})$, calcium (Ca), magnesium (Mg), sodium (Na), boron (B), phosphorus (P), N/B, N/Ca, Ca/B, Ca/Mg, K/Mg, K/Ca, zinc (Zn), copper (Cu), iron (Fe) and manganese $(\mathrm{Mn})(\mathrm{A})$ and physiological disorders $(\mathrm{B})$.

\section{Discussion}

Incidence of physiological disorders in 'Keitt' mangoes

In our study, a total of $29 \%$ of the fruit developed symptoms of the internal physiological disorders known as jelly seed, black flesh or spongy tissue. Similar high physiological disorders incidence of $30 \%$ has been reported in mangoes in previous studies $[2,9,11]$. These results show that physiological disorders can have a great impact on mango losses under commercial conditions. Therefore, studies accomplished to better understand the mechanisms involved can help developing more efficient control approaches and methods to monitor fruit susceptibility to each disorder before and after harvest.

Physical and biochemical factors related to physiological disorders in mango

'Keitt' mangoes showed a reduction in AA content with or without the incidence of internal physiological disorders during the ripening process. In general, tissue damage leads to oxidative stress that reduces AA content in plant tissues [21]. However, our results show that reduction of AA content was similar between healthy and all disordered fruit, suggesting that these disorders are not related to the levels of AA in the fruit. The observed reduction in AA content with ripening is possibly related to oxidative processes that take place during ripening, as reported in other studies [22-25].

\section{Black flesh}

The results obtained show that ready-to-eat mangoes with black flesh symptoms had skin tissue with lower L (darker), C and $\mathrm{b}$ values, compared to healthy mangoes after storage. These results are possibly related to the fact that black flesh causes darkening of the flesh close to the skin in severe cases [11]. Previous studies show that electromagnetic radiation in the visible and infrared region can be used to characterize the physicochemical quality 
of mango flesh at depths of about $10 \mathrm{~mm}$ [26]. Accordingly, other studies have also shown that electromagnetic radiation in the visible region, between 550-650 $\mathrm{nm}$, can be used as a non-destructive method to predict at harvest, as well as detect in ready-to-eat mangoes the incidence of internal physiological disorders [11]. Therefore, $\mathrm{L}, \mathrm{C}$ and $\mathrm{b}$ color data can be used to non-destructively identify ripe mangoes with or without internal black flesh symptoms, ensuring the commercialization of only healthy fruit in the market.

Fruit with black flesh had higher levels of TEP after storage, compared to healthy fruit that had a reduction in TEP levels during storage. Previous studies have shown that the levels of AA, TEP and TAC decrease in mangoes during storage [27], which are possibly due to the oxidative reactions that take place during the ripening process $[24,28]$. Accordingly, in our study, the TEP levels also decreased in healthy mangoes during storage, but not in black flesh fruit possibly due to tissue damage responses caused by the disorder. Polyphenols are known to protect the cells against reactive oxygen species (ROS), and studies have reported that tissue damage responses can lead to higher synthesis of polyphenols in order to proitect the healthy cells against the oxidative damage caused by high ROS levels in the tissue [24,28]. Indeed, other studies have shown that mangoes presenting tissue damage also had an increase in the activity of the phenylpropanoids pathway, leading to higher levels of polyphenols to counteract the increase in tissue oxidative stress. In addition, during black flesh symptoms development, flesh darkening is possibly the result of polyphenol oxidase activity that converts o-diphenols into highly reactive forms known as o-quinones that react with other phenolic compounds and proteins to produce dark-brown pigments [29]. In that case, higher accumulation of TEP in black flesh fruit could also result in higher amount of dark-brown pigments synthesis during tissue damage.

\section{Jelly seed}

The results show that ripe 'Keitt' mangoes with jelly seed had higher skin $h^{\circ}\left(120^{\circ}\right)$ that represents a darker and more intense green color, compared to the skin $\mathrm{H}^{\mathrm{o}}$ value observed in healthy fruit $\left(110^{\circ}\right)$. The $\mathrm{h}^{\circ}$ values ranging from $90^{\circ}$ to $180^{\circ}$ correspond to a variation from less intense to more intense green color, respectively [30].

According to these results, skin $\mathrm{H}^{\circ}$ range from $90^{\circ}$ to $180^{\circ}$ could be used as a non-destructive approach to sort jelly seed 'Keitt' mangoes in the market, ensuring that only healthy fruit are offered to consumers.
'Keitt' mangoes with jelly seed symptoms had lower TEP levels at harvest and higher after storage, compared to healthy mangoes. Similar to the results observed for black flesh fruit, jelly seed fruit possibly increased the synthesis of polyphenols to protect the healthy cells against the oxidative damage caused by high ROS levels in the tissue, as it has been also suggested in other studies [9]. Accordingly, it has been reported that accumulation of phenolic compounds during storage can be a response to oxidative stress that enhances the activity of the phenylpropanoid pathway in order to counteract the increasing ROS levels [31]. In addition, other studies have shown that mango flesh tissue with jelly seed symptoms also have higher polyphenol oxidase (PPO) activity [9], suggesting that accumulation of TEP in flesh tissue is the result of enhanced polyphenols synthesis and breakdown due to ROS and PPO activity.

Fruit that developed jelly seed symptoms had lower TAC, than healthy fruit, both at harvest and after the storage. These results are in agreement with other studies showing that jelly seed incidence reduces flesh tissue TAC [9], which possibly takes place due to the use of antioxidant compounds to eliminate ROS, such as 02•-, $\mathrm{H}_{2} \mathrm{O}_{2}$ and $\mathrm{OH}^{-}$[32], produced during jelly seed tissue damage. Antioxidant compounds are constantly synthesized through different pathways and the tissue TAC is determined by the balance between their synthesis and breakdown on ROS detoxification processes [13,33-35]. In that case, jelly seed fruit possibly had higher ROS/antioxidant synthesis at harvest and during storage, favoring higher tissue damage, compared to healthy fruit.

\section{Spongy tissue}

According to the results, 'Keitt' mangoes that developed spongy tissue during storage showed at harvest higher skin $\mathrm{h}^{\mathrm{o}}\left(118^{\circ}\right)$, which represents more intense green color, compared to the skin $\mathrm{h}$ o observed at harvest in mangoes that did not developed disorders $\left(114^{\circ}\right)$ [30]. In that case, the skin ho could be used at harvest to predict the incidence of spongy tissue in 'Keitt' mangoes during transportation and storage. The skin ho can be analyzed during the fruit classification process to eliminate highly susceptible mangoes, preventing losses with packaging, transportation, disposal, and commercialization of spongy tissue fruit.

Nutritional factors related to physiological disorders in mango

The results showed higher $\mathrm{N}$ levels in black flesh fruit, compared to healthy fruit. Similar results have been reported in other 
studies, suggesting that high $\mathrm{N}$ levels can increase mango susceptibility to physiological disorders, possibly by accelerating fruit growth and limiting other essential nutrients accumulation in the fruit [4]. In addition, fruit that developed black flesh, jelly seed and spongy tissue during storage had lower levels of $\mathrm{Ca}$ and $\mathrm{Mg}$, than healthy fruit. Similar results have been reported in other studies, showing lower levels of $\mathrm{Ca}$ and $\mathrm{Mg}$ in mangoes with internal physiological disorders [4,36-39]. The lower fruit $\mathrm{Ca}$ and $\mathrm{Mg}$ accumulation is possibly related to lower root uptake and/or plant translocation of these nutrients to the fruit $[40,41]$. In addition, our results show that mangoes with black flesh, jelly seed and spongy tissue had higher N/Ca ratios, compared to healthy fruit, suggesting that high $\mathrm{N}$ and/or low Ca could be regulating fruit susceptibility to these internal disorders. High levels of $\mathrm{N}$ have been reported to increase fruit growth rates and limit fruit Ca uptake, diluting $\mathrm{Ca}$ concentration in the flesh [42], which could have increased fruit susceptibility to black flesh, as reported for other fruit disorders [43]. In the case of jelly seed and spongy tissue the higher $\mathrm{N} / \mathrm{Ca}$ ratios were not affected by $\mathrm{N}$ concentration, but by the lower $\mathrm{Ca}$ concentrations, which possibly affected the balance between cell expansion rates and cellular membrane structures and integrity regulated by Ca levels in flesh tissue. The balance between $\mathrm{N} / \mathrm{Ca}$ has been suggested to play an important role on cell membrane structure and function that determines fruit susceptibility to physiological disorders [44]. Indeed, studies have found that high N/Ca ratio is highly correlated with internal physiological disorders in mango $[4,41,45-47]$.

Mangoes that developed black flesh and spongy tissue had lower $\mathrm{Ca} / \mathrm{B}$ ratios, than healthy fruit, which is explained by the lower levels of $\mathrm{Ca}$ in black flesh and spongy tissue fruit. Although B concentrations were similar between healthy and disordered fruit, this nutrient has an important role on fruit growth and development, as well as on uptake and use of Ca by plant tissues [48]. Indeed, studies have reported that mango plants cultivated under low B conditions produce fruit that are more susceptible to internal disorders [49].

The $\mathrm{K} / \mathrm{Ca}$ and $\mathrm{K} / \mathrm{Mg}$ ratios were higher in fruit that developed black flesh, jelly seed and spongy tissue, than in healthy fruit. Similar to the results observed for the $\mathrm{B} / \mathrm{Ca}$ ratio, these higher ratios were obtained due to the lower $\mathrm{Ca}$ and $\mathrm{Mg}$ levels observed in disordered fruit, since $\mathrm{K}$ concentrations was equal between healthy and disordered fruit. Although $\mathrm{K}$ concentration was the same in all fruit, this nutrient is known to compete with $\mathrm{Ca}$ and $\mathrm{Mg}$ for root uptake and translocation to the fruit, which can play also an important role on determining mango Ca uptake and susceptibility to physiological disorders, as reported in other studies [50,51].

Zinc concentration was about two-fold higher in healthy compared to disordered fruit. Zinc plays an important role as a cofactor for several enzymes involved in essential metabolic activities such as alcohol dehydrogenase, glutamic dehydrogenase and carbonic anhydrase [52]. Therefore, lower concentrations of this nutrient could have resulted in metabolic changes that enhanced fruit susceptibility to the internal physiological disorders.

Lower levels of $\mathrm{Cu}$ and Fe were observed in mangoes that developed black flesh and spongy tissue during storage, compared to healthy mangoes. Copper is an important component in ascorbic acid oxidase, tyronase, phenolase anduricase, among others, and Fe is a constituent of cytochromes and iron-proteins, having both nutrients important roles on oxidation and reduction processes in plant tissues vegetables [53]. In that case, low $\mathrm{Cu}$ and $\mathrm{Fe} \mathrm{lev-}$ els could have affected oxy-reduction processes, increasing mango susceptibility to black flesh and spongy tissue disorders.

Higher Mn content was observed in fruit that developed all three internal disorders during storage, compared to healthy fruit. Manganese plays an important role on the activity of many enzymes, some of which are involved in oxidative stress responses, such as superoxide dismutases that catalyzes the conversion of superoxide anion into hydrogen peroxide [53]. However, as a plant micronutrient, Mn levels higher than required by the tissues can lead to excess and possible damages due to interaction with other nutrients involved in oxy-reduction reaction, such as $\mathrm{Cu}$ and Fe. In addition, studies have suggested that the concentration of nutrients such as $\mathrm{N}, \mathrm{P}, \mathrm{Cu}, \mathrm{Fe}$, and $\mathrm{Zn}$ in the plant is affected by the levels of $\mathrm{Mn}$ in the soil solution and plant vascular tissues [54].

Main factors related to the incidence of internal disorders in mango

The principal component analysis was efficient in separating at harvest and after storage healthy and disordered fruit. According to the principal component analysis, mangoes that developed black flesh and spongy tissue symptoms were characterized at harvest by high $\mathrm{N}$ levels and $\mathrm{N} / \mathrm{Ca}$ and $\mathrm{K} / \mathrm{Ca}$ ratios, as well as lower levels of $\mathrm{Ca}, \mathrm{Mg}, \mathrm{Cu}, \mathrm{Fe}$ and $\mathrm{Ca} / \mathrm{B}$ ratio. After storage, mangoes with black flesh and spongy tissue symptoms were characterized by 
lower skin $\mathrm{L}$ (darker), $\mathrm{C}$ and $\mathrm{b}$ values, as well as higher levels of TEP, Mn and N/Ca ratio. Mangoes that developed jelly seed symptoms were characterized at harvest by low levels of TEP and TAC, as well as high levels of $\mathrm{K}, \mathrm{Zn}$ and $\mathrm{Ca} / \mathrm{Mg}$ ratio. After storage, mangoes with jelly seed symptoms were characterized by higher skin $\mathrm{H}^{\circ}$ and lower TAC. The physical and chemical traits associated with each disorder can be used at harvest to predict the disorder incidence in the fruit during storage, as well as in the market to determine the level of each disorder incidence in mangoes. In addition, nondestructive traits, such as skin color parameters, can be used to sort sound and disordered fruit, ensuring that only fruit without physiological disorders will be offered to consumers.

\section{Conclusions}

A total of $29 \%$ of fruit developed internal physiological disorders after reaching the ready-to-eat maturity stage, $11 \%$ with spongy tissue, $9 \%$ with black flesh, and $9 \%$ with jelly seed.

Mangoes that developed black flesh during storage had higher levels of $\mathrm{N}, \mathrm{Mn}$, and $\mathrm{N} / \mathrm{Ca}, \mathrm{K} / \mathrm{Mg}, \mathrm{K} / \mathrm{Ca}$ ratios, as well as lower $\mathrm{Ca}$, $\mathrm{Mg}, \mathrm{Cu}, \mathrm{Fe}, \mathrm{Zn}$ and $\mathrm{Ca} / \mathrm{B}$ ratio compared to healthy mangoes. After storage, mangoes with black flesh had lower skin L (darker), C and $\mathrm{b}$ values, as well as higher TEP levels, compared to healthy mangoes.

'Keitt' mangoes that developed jelly seed during storage had at harvest lower levels of TEP, TAC, $\mathrm{Ca}, \mathrm{Mg}$, and $\mathrm{Zn}$, as well as higher Mn content and $\mathrm{N} / \mathrm{Ca}, \mathrm{Ca} / \mathrm{Mg}, \mathrm{K} / \mathrm{Mg}$, and $\mathrm{K} / \mathrm{Ca}$ ratios, compared to healthy mangoes. After storage, mangoes with jelly seed symptoms had higher skin $\mathrm{h}^{\circ}$ and TEP levels, as well as lower TAC, compared to healthy mangoes.

'Keitt' mangoes that developed spongy tissue had at harvest higher skin $\mathrm{h}^{\circ}$, lower levels of $\mathrm{Ca}, \mathrm{Mg}, \mathrm{Zn}, \mathrm{Cu}, \mathrm{Fe}$ and $\mathrm{Ca} / \mathrm{B}$ ratio, as well as higher $\mathrm{Mn}$ levels and $\mathrm{N} / \mathrm{Ca}, \mathrm{K} / \mathrm{Mg}, \mathrm{K} / \mathrm{Ca}$ ratios, compared to healthy mangoes.

The skin $\mathrm{h}^{\circ}$ and TEP levels in flesh tissue have the potential to predict at harvest and determined after storage the incidence of spongy tissue and jelly seed in 'Keitt' mangoes, respectively. Skin $\mathrm{L}, \mathrm{C}$ and $\mathrm{b}$ values have the potential to non-destructively determine the presence of black flesh in ready-to-eat 'Keitt' mangoes. Mangoes that developed black flesh, jelly seed and spongy tissue during storage had at harvest low levels of $\mathrm{Ca}, \mathrm{Mg}$, and $\mathrm{Zn}$, as well as high Mn levels, compared to healthy fruit.
More studies are required to determine the level of each physicochemical and nutritional trait that can be used as an index to predict at harvest or identify ready-to-eat fruit with physiological disorders.

\section{Author Contribution}

- $\quad$ Sergio Freitas: Study coordination, methodology, reviewing, editing and submitting the manuscript to publication.

- Matheus Andrade: Carrying out the study, analyzing samples and data, writing the original draft.

- Bárbara Silva, Tiffany Ribeiro and Luana Santos: Analyzing samples and data, reviewing the manuscript.

- Augusto Lima and Fábio Oliveira: Nutrient analyses and reviewing the manuscript.

\section{Funding}

This study was supported by the mango grower Agropecuária Roriz Dantas (AGRODAN) and the Brazilian Agricultural Research Corporation, Embrapa.

\section{Declaration of Competing Interests}

The authors declare that they have no known competing financial interests or personal relationships that could have appeared to influence the work reported in this paper.

\section{Acknowledgments}

The authors would like to thank the Brazilian National Council for Scientific and Technological Development (CNPq) for the Research Productivity scholarship granted to the corresponding author, and for the undergraduate scholarship. The authors also would like to thank the Coordenação de Aperfeiçoamento de Pessoal de Nível Superior (CAPES) for the master's degree scholarship and the Fundação de Amparo a Ciência e Tecnologia do Estado de Pernambuco (FACEPE) for the postdoctoral and undergraduate scholarships.

\section{Bibliography}

1. "Anuário Brasileiro Da Fruticultura". Santa Cruz do Sul: Ed. Gazeta Santa Cruz (2019): 90.

2. Seshadri S., et al. "Preventive regulation of jelly seed disorder in 'Amrapali' mango (Mangifera indica) by preharvest spray". Horticultural Plant Journal 5 (2019): 70-78. 
3. Gabriëls SH., et al. "Non-destructive measurement of internal browning in mangoes using visible and near-infrared spectroscopy supported by artificial neural network analysis". Postharvest Biology and Technology 166 (2020): 111206.

4. Assis JSD., et al. "Nutritional balance and physiological disorders in 'Tommy Atkins' mango". Revista Brasileira de Fruticultura 26 (2004): 326-329.

5. Brecht JK. “Mango”. In: de Freitas, S.T., Pareek, S. (Eds.). Posharvest Physiological Disorders in Fruit and Vegetables. CRC Press, Boca Raton Florida (2019): 443-466.

6. Machado WRB. "Avaliação das perdas de manga no mercado varejista do Vale do São Francisco". Revista Agroambiental 10 (2017): 75-90.

7. Ledesma N and Campbell RJ. "The status of mango cultivars, market perspectives and mango cultivar improvement for the future". Acta Horticulturae 1244 (2019): 23-27.

8. Shivashankar S., et al. "Premature seed germination induced by very-long-chain fatty acids causes jelly seed disorder in the mango (Mangifera indica L.) cultivar 'Amrapali' in India". Journal of Horticultural Science and Biotechnology 91 (2016): 138-147.

9. Krishna KR., et al. "Physiological and biochemical attributes associated with jelly seed disorder in mango (Mangifera indica L.)". Acta Physiologiae Plantarum 42 (2020): 1-12.

10. Raymond L., et al. "Internal breakdown in mango fruit: symptomology and histology of jelly seed, soft nose and stem-end cavity". Postharvest Biology and Technology 13 (1998): 59-70.

11. Mogollón R., et al. "Postharvest biology and technology nondestructive prediction and detection of internal physiological disorders in 'Keitt' mango using a hand-held Vis-NIR spectrometer". Postharvest Biology and Technology 167 (2020): 1-7.

12. Acosta-Ramos M., et al. "Black flesh in Haden mango fruit during postharvest". Revista Chapingo, Serie Horticultura 7 (2001): 131-141.

13. Oak P., et al. "Metabolomic dynamics reveals oxidative stress in spongy tissue disorder during ripening of Mangifera indica $\mathrm{L}$. fruit". Metabolites 9 (2019): 1-23.

14. Strohecker R and Henning HM. "Analisis de vitaminas: métodos comprobados". Madrid: Paz Montalvo (1967): 428.
15. Sánchez-Moreno C., et al. "A procedure to measure the antiradical efficiency of polyphenols". Journal of the Science of Food and Agriculture 76 (1998): 270-276.

16. Rufino MM., et al. "Bioactive compounds and antioxidant capacities of 18 non-traditional tropical fruits from Brazil". Food Chemistry 121 (2010): 996-1002.

17. Larrauri JA., et al. "Effect of drying temperature on the stabilitity of polyphenols and antioxidant activity of red grape pomace peels". Journal of Agriculture and Food Chemistry 5 (1997): 1390-1393.

18. Thomas RL., et al. "Comparation of conventional and automated procedures for N, P and K analysis of plant material using a single digestion". Agronomy Journal 59 (1967): 240-243.

19. Silva FC. "Manual de análises químicas de solos, plantas e fertilizantes. 2. ed. rev . ampl. - Brasília, DF”. Embrapa Informação Tecnológica (2009): 627.

20. Zulkifli KS., et al. "Bioactive phenolic compounds and antioxidant activity of selected fruit peels. In: International Conference on Environment". Chemistry and Biology 49 (2012): 6670.

21. Kim H., et al. "Antioxidant and antiproliferative activities of mango (Mangifera indica L.) flesh and peel". Food Chemistry 121 (2010): 429-436.

22. Robles-Sánchez RM., et al. "Effect of minimal processing on bioactive compounds and antioxidant activity of fresh cut 'Kent' mango (Mangifera indica L.)". Postharvest Biology and Technology 51 (2009): 384 - 390.

23. Robles-Sánchez RM., et al. "Influence of alginate-based edible coating as carrier of antibrowning agents on bioactive compounds and antioxidant activity in fresh-cut Kent mangoes". LWT - Food Science and Technology 50 (2013): 240-246.

24. Ibarra-garza IP., et al. "Effects of postharvest ripening on the nutraceutical and physicochemical properties of mango (Mangifera indica L. cv Keitt)". Postharvest Biology and Technology 103 (2015): 45-54.

25. Hu K., et al. "Phytochemical profiling of the ripening of Chinese mango (Mangifera indica L.) cultivars by real-time monitoring using UPLC-ESI-QTOF-MS and its potential benefits as prebiotic ingredients". Food Chemistry 256 (2018): 171-180. 
26. Marques EJN., et al. "Rapid and non-destructive determination of quality parameters in the 'Tommy Atkins' mango using a novel hand-held near infrared spectrometer". Food Chemistry 197 (2016): 1207-1214.

27. Alves JA., et al. "Kinects of vitamin C degradation of 'Palmer' mangoes (Mangifera indica L.) stored at different temperatures". Ciência e Agrotecnologia 34 (2010): 714-721.

28. Palafox-Carlos H., et al. "Effect of ripeness stage of mango fruit (Mangifera indica L., cv. Ataulfo) on physiological parameters and antioxidant activity". Scientia Horticulturae 135 (2012): 7-13.

29. Tomás-Barberán F and Espín JC. "Phenolic compounds and related enzymes as determinants of quality in fruits and vegetables". Journal of the Science of Food and Agriculture 81 (2001): 853-876.

30. McGuire RG. "Reporting of objective color measurements". HortScience 27 (1992): 1254-1255.

31. Rice-Evans CA., et al. "Antioxidant properties of phenolic compounds". Trends in Plant Science 2 (1997): 152-159.

32. Rosalie R., et al. "Antioxidant and enzymatic responses to oxidative stress induced by pre-harvest water supply reduction and ripening on mango (Mangifera indica L. cv. 'Cogshall') in relation to carotenoid content". Journal of Plant Physiology 184 (2015): 68-78.

33. Nagamani JE., et al. "Role of oxidative stress and the activity of ethylene biosynthetic enzymes on the formation of spongy tissue in 'Alphonso' mango". Journal of Food Science and Technology 47 (2010): 295-299.

34. Zsigmond L., et al. "Enhanced activity of galactono-1,4-lactone dehydrogenase and ascorbate-glutathione cycle in mitochondria from complex III deficient Arabidopsis". Plant Physiology and Biochemistry 49 (2011): 809-815.

35. Niranjana R., et al. "Carotenoids modulate the hallmarks of cancer cells". Journal of Functional Foods 18 (2015): 968-985.

36. Burdon JN., et al. "Mineral distribution in mango fruit susceptible to the physiological disorder soft nose". Scientia Horticulturae 48 (1991): 329-336.

37. Sampaio VR., et al. "Physiological disorders in mango: effect of foliar sprays with calcium". Scientia Agricola 56 (1999): 459463.
38. Sharma RR and Singh R. "The fruit pitting disorder-A physiological anomaly in mango (Mangifera indica L.) due to deficiency of calcium and boron". Scientia Horticulturae 119 (2009): 388-391.

39. Santos AM., et al. "Determination of mineral contents in mango pulp (Mangifera indica L.) of different cultivars". Brazilian Journal of Development 6 (2020): 71888-71895.

40. Marchner H. "Mineral nutrition of higher plants. 2nd ed". London: Academic Press, 1995. 889.

41. Silva DJ., et al. "Quality and nutrient level of mango cv. Tommy Atkins as affected by calcium application before harvest". Revista Brasileira de Fruticultura 30 (2008): 74-78.

42. Kulkarni SG and Vijayanand P. "Effect of extraction conditions on the quality characteristics of pectin from passion fruit peel (Passiflora edulis f. flavicarpa L.)". LWT - Food Science and Technology 43 (2010): 1026-1031.

43. Amarante CVT., et al. "Preharvest identification of bitter pit risk in 'Gala' apples by fruit infiltration with magnesium and analysis of fruit contents of calcium and nitrogen". Revista Brasileira de Fruticultura 32 (2010): 27-34.

44. Freitas ST., et al. "Mechanisms regulating apple cultivar susceptibility to bitter pit". Scientia Horticulturae 186 (2015): 54-60.

45. Cracknell Torres A and Galán Saúco V. "The study of the problem of mango (Mangifera indica L.) internal breakdown". Acta Horticulturae 645 (2004): 167-174.

46. Karemera NJU and Habimana S. "Effect of pre-harvest calcium chloride on post-harvest behavior of mango fruits (Mangifera indica L.) cv. Alphonso". Universal Journal of Agricultural Research 2 (2014): 119-125.

47. Singh P., et al. "A critical overview on various physiological disorders of mango (Mangifera indica L.)". Trends in Biosciences 10 (2017): 5913-5916.

48. Saran PL and Kumar R. "Boron deficiency disorders in mango (Mangifera indica): field screening, nutrient composition and amelioration by boron application". Indian Journal of Agricultural Sciences 81 (2011): 506-510.

49. Carvalho CIFS., et al. "Stenospermocarpy in mango fruits and the relationship with boron nutrition". Meio Ambiente 2 (2020): 58-67. 
50. Bindra OS and Bakhetia DRC. "Investigations on etiology and control of mango malformation". Indian Journal of Horticulture 28 (1971): 80-85.

51. Ram RA., et al. "Diagnosis and management of nutrient constraints in mango". Fruit Crops 1 (2020): 629-650.

52. Mishra DS., et al. "Review on physiological disorders of tropical and subtropical fruits: Causes and management approach". International Journal of Agriculture, Environment and Biotechnology 9 (2016): 925-935.

53. Shukla AK., et al. "Micronutrients in soils, plants, animals and humans". Indian Journal of Fertilisers 14 (2018): 30-54.

54. Veloso CAC., et al. "Effect of manganese on mineral nutrition and growth of black pepper (Piper nigrum, L.)". Scientia Agricola 52 (1995): 376-383.

\section{Assets from publication with us}

- Prompt Acknowledgement after receiving the article

- Thorough Double blinded peer review

- Rapid Publication

- Issue of Publication Certificate

- High visibility of your Published work

Website: www.actascientific.com/

Submit Article: www.actascientific.com/submission.php

Email us: editor@actascientific.com

Contact us: +919182824667 